НАУКОВИЙ ВІСНИК

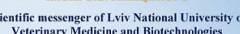

(4)

RIES: VETERINARY SCIENC
Науковий вісник Аьвівського національного університету ветеринарної медицини та біотехнологій імені С.3. Гжицького. Серія: Ветеринарні науки

Scientific Messenger of Lviv National University of Veterinary Medicine and Biotechnologies. Series: Veterinary sciences

UDC 619:616/992:616-084:636.2

\title{
Ungulomycosis of cattle: treatment and preventive measures
}

\author{
A. R. Mysak, Y. M. Lenjo, B. V. Gutyj, Ya. G. Krupnyk, S. V. Tsisinska, I. I. Iglitskyj, I. P. Dudchak \\ Stepan Gzhytskyi National University of Veterinary Medicine and Biotechnologies Lviv, Ukraine
}

Article info

Received 12.08.2021

Received in revised form 13.09 .2021

Accepted 14.09.2021

Stepan Gzhytskyi National University of Veterinary Medicine and Biotechnologies Lviv, Pekarska Str., 50, Lviv, 79010, Ukraine. Tel.: +38-093-985-15-22 E-mail: yurijlenyo@gmail.com
Mysak, A. R., Lenjo, Y. M., Gutyj, B. V., Krupnyk, Ya. G., Tsisinska, S. V., Iglitskyj, I. I., \& Dudchak, I. P. (2021). Ungulomycosis of cattle: treatment and preventive measures. Scientific Messenger of Lviv National University of Veterinary Medicine and Biotechnologies. Series: Veterinary sciences, 23(103), 168-178. doi: 10.32718/nvlvet10324

Of the total number of animal diseases, 70-80\% are non-communicable diseases, and more than 50\% are surgical diseases, which cause significant economic damage to the livestock industry due to reduced productivity and premature culling of livestock. Irrational, unbalanced in terms of macro- and microelements, vitamins, carbohydrates feeding leads to metabolic disorders. At the same time, deep destructive-degenerative changes in bones, joints, ligaments and tendons are registered, horn formation in the hooves is disturbed and a less stable horn is produced. Omission in feeding unsatisfactory housing conditions and inadequate care of animals. When such conditions are often supplemented, the outer cover of animals, in particular the hooves, is affected first of all. In the event of inflammatory and dystrophic processes at the base of the skin of the hooves there is a violation of tissue (tubular) and cellular structure. The horn of such hooves undergoes changes in the form of parakeratosis and deformation; this contributes to the spread and accumulation of fungal flora, which shows its pathogenic action mainly due to enzymatic activity and toxic products, which characterizes these microorganisms as a factor in the destructive processes of the hoof horn. With reduced mechanical stability and destroyed by microscopic fungi of hoof horn is more likely to develop aseptic or purulent pododermatitis. Here, the fungal flora is not only a contributing factor in the occurrence of diseases, but also as one of the factors complicating the course of the disease. That is why timely detection and effective treatment of ungulomycosis prevents the complication of the pathological process, which can even lead to culling of animals. The essence of treatment of superficial ungulomycosis is reduced to functional cleaning of hooves and their antiseptic treatment in the form of fungicidal powders, sprays, hoof baths. In deep ungulomycosis, and, moreover, in combination with purulent pododermatitis, treatment includes local anesthesia, orthopedic treatment, antiseptic treatment with isolation, pathogenetic therapy. Prevention of ungulomycosis is based on knowledge of the etiology of the disease and the pathogenetic mechanisms of its development. Its essence is to form in animals a strong hoof horn, prevent its destruction and eliminate favorable conditions for the reproduction of keratomycetes. This includes proper feeding, proper housing conditions and appropriate animal care.

Key words: cattle, hoof horn, microscopik fungi-keratomycetes, ungulomycosis, osteodystrophy, hoof deformity, pododermatitis, treatments, measures to prevent.

\section{Унгуломікоз великої рогатої худоби: лікування й профілактичні заходи (огляд літератури)}

\author{
А. Р. Мисак, Ю. М. Леньо, Б. В. Гутий, Я. Г. Крупник, С. В. Цісінська, І. І. Ігліцький, І. П. Дудчак
}

Львівський національний університет ветеринарної медищини та біотехнологій імені С. 3. Гжицького, м. Львів, Україна

Із загального числа захворювань тварин 70-80\% припадає на незаразні хвороби, при цьому більше ніж 50 \% з них - на хірургічні, які завдають галузі тваринниитва значних економічних збитків внаслідок зниження продуктивності та передчасного вибраковування тварин. Нераціональна, незбалансована за макро- і мікроелементами, вітамінами, вуглеводами годівля призводить до 
порушення обміну речовин. При иьому реєструються глибокі деструктивно-дегенеративні зміни в кістках, суглобах, зв'язках $i$ сухожилках, порушується рогоутворення в копитцях й продукується менш стійкий ріг. Упущення в годівлі часто доповнюються незадовільними умовами утримання та невідповідним доглядом за тваринами. При изьоу насамперед уражуються копития. При виникненні запальних і дистрофічних прочесів в основі шкіри копитець настає порушення тканинної (трубчастої) $і$ клітинної структури. Ріг таких копитецьь зазнає змін у вигляді паракератозу та деформації; ие сприяє поширенню й накопиченню грибкової флори, яка проявляє свою патогенну дію, головним чином, за рахунок ферментативної активності та токсичних продуктів, ицо характеризує иі мікроорганізми як чинник деструктивних процесів копитцевого рогу. За зниженої механічної стійкості та зруйнованого мікроскопічними грибами копитцевого рогу є більша ймовірність виникнення асептичного чи гнійного пододерматиту. Тут грибкова флора є не тільки фактором, щзо сприяє виникненню циих захворювань, а й одним із чинників ускладнення їхнього перебігу. Саме тому своєчасне виявлення й ефективне лікування тварин за унгуломікозу запобігає ускладненню патологічного процесу, який може призвести навіть до вибраковування тварин. У випадках поверхневого унгуломікозу суть лікування зводиться до розчистки копитець та їхньої антисептичної обробки у вигляді фунгіцидних присипок, спреїв, копитцевих ванн. За глибокого унгуломікозу, а тим паче у поєднанні з гнійним пододерматитом, лікування включає місцеве знеболювання, ортопедичну розчистку, антисептичну обробку з накладанням захисної пов'язки, патогенетичну терапію. Профілактика унгуломікозу трунтується на знанні етіологї захворювання та патогенетичних механізмів його розвитку. Суть ї̈ зводиться до формування у тварин міцного копитцевого рогу, запобігання його руйнування та усунення сприятливих умов для розмноження кератоміцетів. Сюди належать повноцінна годівля, відповідні умови утримання та догляд за тваринами.

Ключові слова: велика рогата худоба, копитиевий ріг, мікроскопічні гриби-кератоміцети, унгуломікоз, остеодистрофія, деформація копитець, пододерматит, лікування, профілактика.

\section{Вступ}

Iз загального числа захворювань тварин 70-80\% припадає на незаразні хвороби, при цьому понад 50 \% 3 них - на хірургічні, які завдають галузі тваринництва значних економічних збитків внаслідок зниження продуктивності та передчасного вибраковування тварин (Veremej et al., 1989; Borysevych, 1993; Veremej \& Zhurba, 2003; Panko, 2003; Stekol'nikov et al., 2016).

Неповноцінна годівля призводить до порушення обміну речовин; при цьому реєструються глибокі деструктивно-дегенеративні зміни в кістках, суглобах, зв'язках і сухожилках, порушується рогоутворення в копитцях й продукується менш стійкий ріг. Упущення в годівлі часто доповнюються незадовільними умовами утримання та невідповідним доглядом, які призводять до ураження копитець (Veremej \& Zhurba, 2003; Luk'janovskij, 2005; Kirillov, 2007; Mar'in et al., 2012; Rukol', 2013). Внаслідок виникнення запальних і дистрофічних процесів в основі шкіри копитець копитцевий ріг зазнає змін у вигляді паракератозу й деформацiï (Borisevich, 1996; Kovalchuk \& Kuzheliuk, 2015; Mar'in et al., 2017). Це сприяє поширенню й накопиченню грибкової флори, яка проявляє свою патогенну дію за рахунок ферментативної активності та токсичних продуктів, що підвищує їхню конкурентну здатність за засвоєння субстрату, і характеризує мікроорганізм як чинник деструктивних процесів копитцевого рогу (Izdepskyi et al., 2012).

Здебільшого за унгуломікозу (від лат. ungula - копито, гр. mykes - гриб) найчастіше реєструються його ускладнення, а не саме захворювання, що не дозволяє своєчасно проводити ефективні профілактичні заходи та лікування тварин (Krupnyk et al., 2021).

\section{Результати та їх обговорення}

Враховуючи багатофакторність етіологічних чинників, котрі можуть сприяти появі та розвитку захворювань дистального відділу кінцівок у великої рогатої худоби, зокрема копитець, проводять комплексне дослідження стану тваринницьких приміщень та їхньої відповідності санітарно-гігієнічним нормам. Окрему увагу приділяють проекційним характеристикам стійл для тварин, покриттю підлоги та системі прибирання гною.

В ході проведення хірургічної (клінікоортопедичної) диспансеризації проводять огляд тварин, звертають увагу на вгодованість, положення тіла та поставу кінцівок і пальців, оцінюючи їх статичну та динамічну функції (Borisevich, 1996; Hulek, 2015; Kantemyr et al., 2016; Spitsyna et al., 2016; Nenashev et al., 2018; Chehodaridi \& Guchkaeva, 2019; Krasnoperov et al., 2020; Rudyk et al., 2021).

За неправильної постави кінцівок, яка є вродженою чи набутою, має місце нерівномірне навантаження й надмірне стирання окремих ділянок копитець, що зумовлює зміну їхньої форми. Відповідно ж зміна форми копитець впливає на поставу кінцівок. Особливо сильно це виражено у випадку запущеної деформації копитець.

Встановлено (Borisevich, 1996), що значні відхилення в поставі кінцівок внаслідок погіршення їх опорної функції виникають за остеодистрофії, внаслідок чого спостерігаються масові захворювання копитець. За порушеної постави тазових кінцівок, зумовленої остеодистрофією, різко змінюється характер опори копитець - опора здійснюється, головним чином, м'якушами; копитця стають лижоподібними (рис. 1). 

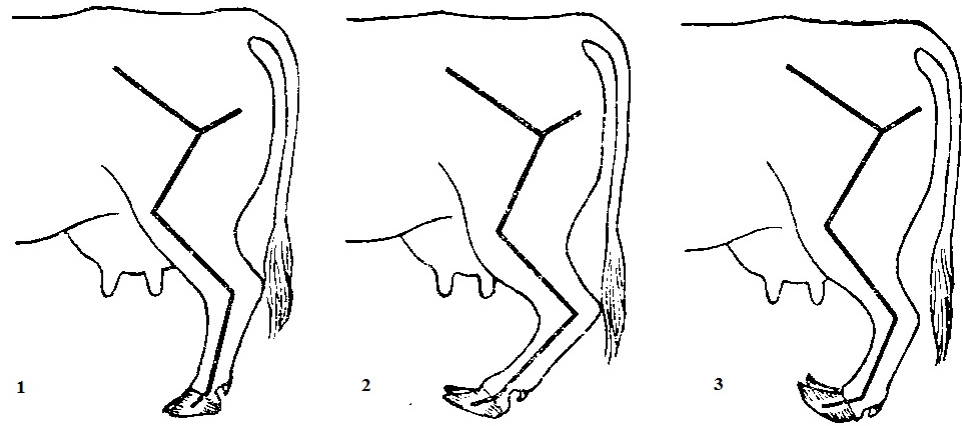

Рис. 1. Варіанти постави тазових кінцівок (Borysevych, 1993; Borisevich, 1996):

1) надмірно зігнута в колінному суглобі; 2) надмірно зігнута в заплесновому суглобі; 3) надмірно розігнута в суглобах пальців

Як відомо (Hulek, 2015), проблеми проявляються, головним чином, на задніх зовнішніх копитцях, адже ті ростуть інтенсивніше, ніж внутрішні, внаслідок більшого навантаження. Оскільки корова намагається опиратися на обидва копитця, чого вона, у випадку більшої висоти зовнішнього копитця, може досягнути, поставивши нижню частину кінцівки навскоси, при цьому зачепи копитець розвертаються назовні, а скакальні суглоби - всередину. Внаслідок цього формується Х-подібна постава кінцівок.

При оцінці постави кінцівок за М. Хулек (Hulek 2015) (рис. 2) беруть до уваги кут між продовженою назад віссю міжкопитцевої щілини і поздовжньою віссю (хребтом) корови. Виділяють три ступені:

1 ступінь: 0-17 - тазові кінцівки розміщені (майже) паралельно, зовнішнє і внутрішнє копитця (майже) однакової висоти. В стаді таку поставу кінцівок мають мати більш ніж $3 / 4$ всіх корів.

2 ступінь: 17-23 - зовнішнє копитце вище, ніж внутрішне. В цю групу потрапляють також тварини 3 правильно розчищеними щойно копитцями, у яких ще не відновились кістки і суглоби.

3 ступінь: більше ніж $23^{\circ}$ - у таких тварин зовнішні копитця помітно вищі; вони потребують термінової розчистки, щоб корова не стала кульгавою.

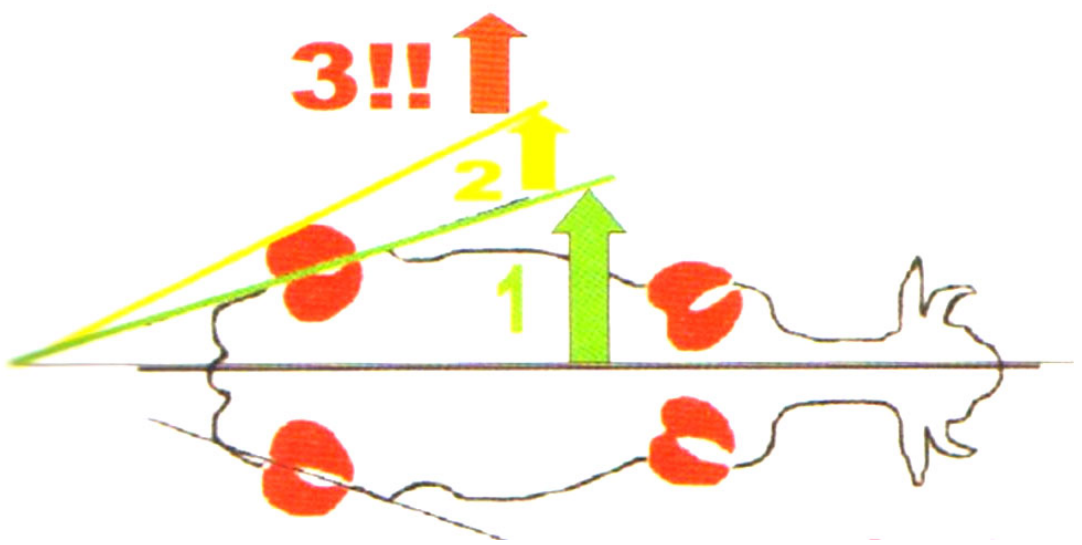

Рис. 2. Оцінка постави кінцівок (Hulek, 2015)

Оцінку стану кінцівок виконують під час проводки тварини, щоб встановити наявність чи відсутність кульгавості, на навантаженій та припіднятій і зафіксованій кінцівці. Оцінюють величину і форму копитець, стан тканин, характер відростання й стирання копитцевого рогу. Особливу увагу приділяють тваринам із деформацією копитець, надмірною гіпертрофією та ознаками руйнування копитцевого рогу.

Клінічні дослідження, які полягають у визначенні характеру місцевого процесу, проводять шляхом огляду та пальпації з використанням пробних щипців.

За необхідності, в ході проведення клінічного дослідження місцевого процесу проводять механічну очистку копитець (механічну антисептику). Тупим краєм копитного ножа чи іншим пристосованим інструментом 3 копитець видаляють бруд, камінці й засохлий гній. Використання води для очистки, через створення болотної плівки є обмеженим. Рекомендується (Hulek, 2015) застосовувати воду лише для очистки шкіри навколо копитець і міжкопитцевої щілини, щоби побачити зміни форми і зауважити ознаки можливих дефектів.

При проведенні розчистки звертають увагу на стан бокової та підошовної частини копитцевого рогу (тріщини, рани, наявність зон пігментації, крововиливів та болючості), наявність чи відсутність виразок м'яких тканин (вінчика, м'якуша, склепіння міжпальцевої щілини), пододерматиту і ламініту, тіломи, виразки Рустергольца, хвороби Мортелларо, гнійних ран та забоїв.

В етіопатогенезі унгуломікозу задіяні такі складові: а) мікроскопічні гриби-кератоміцети; б) травмова- 
ний чи зі зниженою механічною стійкістю копитцевий ріг; в) сприятливі умови для розмноження кератоміцетів та супутньої симбіотичної мікрофлори (рис. 3). Встановлено (Malishevs'kij et al., 1991; Kulynych, 2012; Izdepskyi et al., 2012; Khomyn et al.,
2017; 2020; Krupnyk et al., 2021), що зниження механічної стійкості та руйнування кератоміцетами копитцевого рогу призводить до розвитку ускладнень деформацій копитець, пододерматиту, ураження копитцевої кістки.

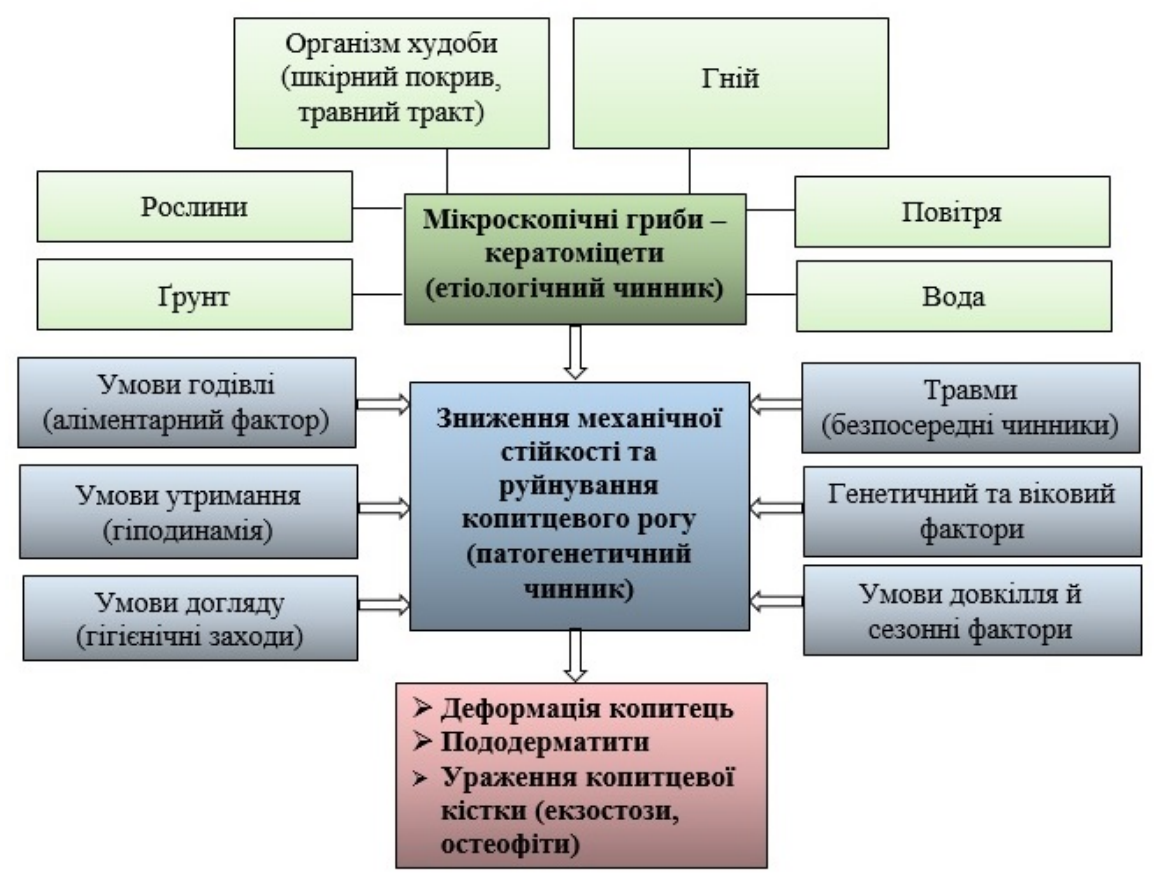

Рис. 3. Схема етіопатогенезу унгуломікозу

Етіологічна роль мікроскопічних грибів- фактор (рис. 4). Саме тому своєчасне й ефективне кератоміцетів за унгуломікозу є основною, тимчасом лікування унгуломікозу запобігає ускладненню патояк за пододерматиту травматичного походження може логічного процесу, який може призвести до вибракобути допоміжною, - як додатковий чи сприяючий вування тварин.

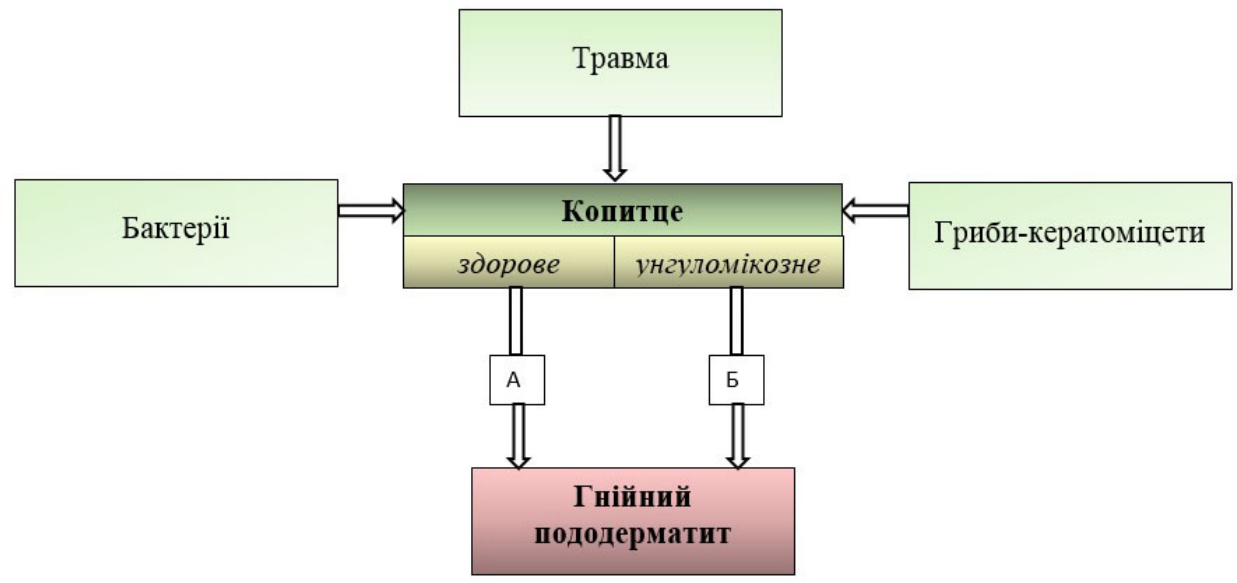

Рис. 4. Схема етіопатогенезу гнійного пододерматиту, ускладненого кератоміцетами (А - додатковий фактор; Б - сприяючий фактор)

Діагноз ставлять на основі клінічних ознак захворювання $з$ урахуванням анамнезу, аналізу годівлі, догляду й утримання тварин, беруть до уваги динаміку біохімічних показників крові та результатів мікробіологічних досліджень.

При виявленні унгуломікозу насамперед визначають ступінь ураження копитцевого рогу, що відповідно впливає на схему лікування тварини. Лікування поверхневого унгуломікозу грунтується на розчистці копитець та їх антисептичній обробці у вигляді фунгіцидних присипок, спреїв, копитцевих ванн. У випадку глибокого унгуломікозу, особливо за гнійного пододерматиту, схема лікування включає: місцеве знеболювання, ортопедичну розчистку, антисептичну обробку з накладанням захисної пов'язки, патогенетичну терапію. 
Оцінка стану копитець

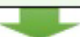

Механічна очистка копитець (механічна антисептика)

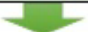

Місцеве знеболювання (за глибокого унгуломікозу та гнійного пододерматиту)

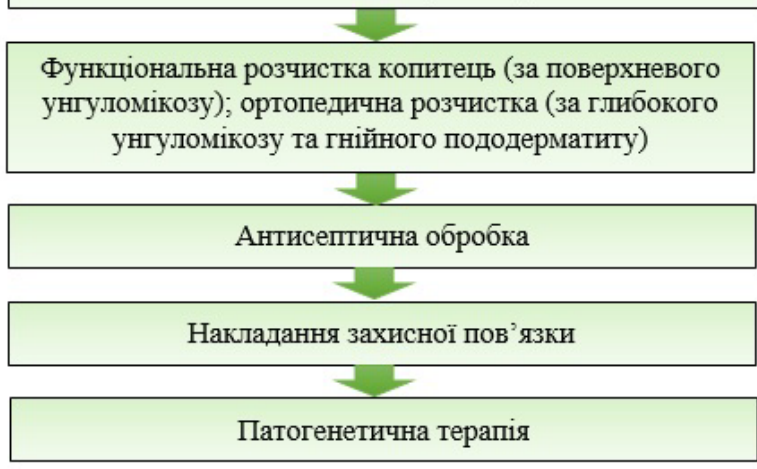

Рис. 5. Схема лікування за унгуломікозу

Для знеболювання дистального відділу кінцівки, зокрема пальців, використовують провідникову та інфільтраційну анестезії (Mahda et al., 1995; Vlasenko \& Tykhoniuk, 2000; Vlasenko et al., 2006).

Найбільш простим та ефективним методом провідникової анестезії $є$ метод Шаброва. При цьому вводять 2-4 \% розчин новокаїну в кількості 15-20 мл на 5-7 см нижче від зап'ясткового (заплеснового) суглоба по краях сухожилків згиначів і розгиначів як з латерального, так і медіального боків.

За методом Регнері пальці знеболюють 3 двох точок. Голку вколюють почергово як 3 медіального, так і латерального боку п’ястка (плесна) на 1-2 (1,5-3) см вище від рівня рудиментарних пальців й дещо дорсальніше від середини бокової поверхні. Ін'єктують по 40-50 мл 3-4 \% розчину новокаїну з кожного боку в дорсальному і волярному (плантарному) напрямах.

Міжпальцеву новокаїнову блокаду виконують 3 дорсального боку шляхом введення 20-40 мл 3-4\% розчину новокаїну в міжпальцеву клітковину, просуваючи голку в бік волярної (плантарної) поверхні.

При розчистці копитець необхідно дотримуватись принципу - краще залишити достатньо рогу, ніж його надмірно видалити (Borisevich, 1996; Hulek, 2015).

В основі методики розчистки копитець у корів за M. Хулек (Hulek, 2015) покладені такі принципи:

- навантаження на суміжну пару копитець має бути розподілене однаково - для чого копитця повинні бути однакової довжини і висоти. У здорових копитцях - якщо підошва при сильному натисканні великого пальця прогинається, то в задній частині опірної поверхні ріг не зрізають.

- розподіл маси тіла в передніх 2/3 підошви здійснюється таким чином, щоб опірна поверхня підошви була під кутом 90 до поздовжньої осі трубчастої кістки. Це забезпечує рівномірне навантаження лис- точків дерми в ділянці стінки, а копитцева кістка перебуває - у правильній позиції.

- опірна поверхня має залишатися максимально великою, що забезпечує розподіл навантаження на більшій площі поверхні й зменшує тиск на дерму.

- дерма має бути захищена достатньо товстим шаром рогу.

- за пошкодження окремого копитця - інше, здорове, вимушене на якийсь час приймати на себе більше навантаження.

Насамперед необхідно виконати функціональну розчистку копитець 3 метою розвантаження дефектного копитця. При цьому обов'язково розчищають обидві кінцівки - передні чи задні. Розмір клиноподібного розвантаження хворого копитця залежить від його стану. Висоту суміжного здорового (частіше меншого) копитця намагаються залишити такою ж, оскільки воно нестиме більше навантаження. Якщо здорове копитце досить низьке чи низько зрізане, то розвантаження хворого копитця необхідно виконати за допомогою штучної накладки. Накладка наклеюється тільки на здорове й правильно зрізане копитце 3 достатнім шаром підошви (5 мм).

Обрізаючи надмірно відрослий ріг, намагаються надати копитцям правильної форми, яка забезпечує фізіологічний розподіл опорно-силових взаємодій у їх структурах, головним чином за активної амортизаційної функції м'якушів, що в кінцевому підсумку сприяє нормальному функціонуванню механізму пальців і копитець.

За деформацій копитець (рис. 6) створюється “замкнуте коло”: надмірно відрослий ріг зумовлює травмування основи шкіри, а викликане запалення та викривлення сосочків і листочків поглиблює неправильний ріст копитцевого рогу. При наявності ускладненої запальними й деструктивними процесами деформації необхідно проводити різні лікувальні процедури (Borisevich, 1996).

Враховуючи ймовірність глибокого проникнення мікроорганізмів, у тому числі збудників унгуломікозу, в рогову субстанцію копитець (рис. 7), проводять ретельну їх розчистку із обов'язковим повним видаленням рогу, що розпався. Розчистку починають 3 підошовної поверхні копитець. Ріг підошви і підошовної ділянки м'якуша звільняють від нашарованого на нього рогу центрального відділу м'якуша чи від покритого рогу стінок. Особливо уважно розчищають аксіальний жолобок, звертаючи увагу на стан рогу білої лінії, який може руйнуватися чи просочуватися ексудатом (за ламініту). Розчищаючи центральну ділянку м'якуша, звертають увагу на наявність характерних для унгуломікозу терасоподібних заглиблень чи борозн, заповнених масою, що неприємно пахне. Під час зрізання рогу підошовних країв копитцевих стінок слід забезпечити його виступання не менше ніж на 2 мм за межі рівня рогу підошовної ділянки м'якуша (на одному рівні з рогом центральної ділянки м'якуша). 


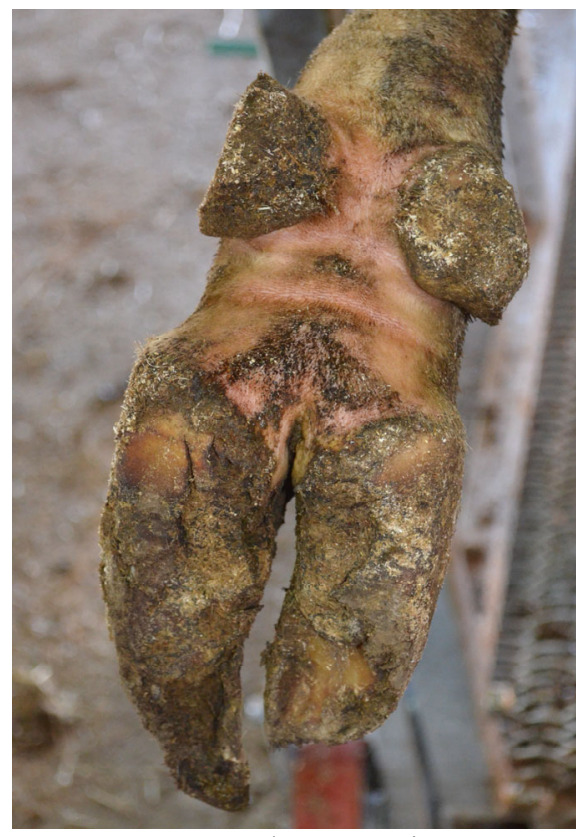

Рис. 6. Деформовані копитця

Для лікування тварин, уражених мікозами, застосовують препарати місцевої та системної дії (табл. 1) При місцевому лікуванні враховують не тільки активну дію препарату, а і його лікарську форму. Відомо (Kaniuka, 2006), що лініменти та мазі, приготовлені на зневодненому ланоліні, рослинних оліях або тваринних жирах, проявляють кращий терапевтичний ефект. Не застосовують мінеральні олії, зокрема вазелін; вони затримують проникнення фунгіцидних препара-

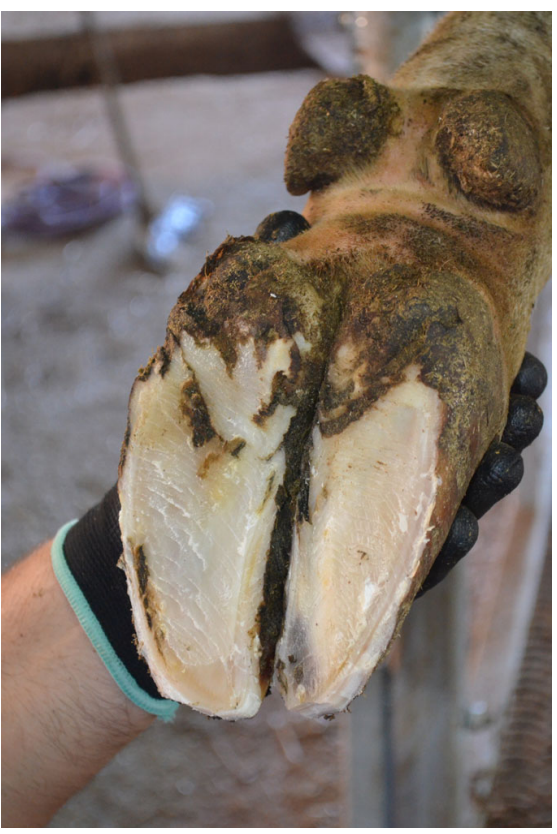

Рис. 7 Локальні глибокі мікотичні ураження підошви

тів у глибокі шари шкіри. Перевагу віддають прогірклим жирам і оліям; при згіркненні жиру ненасичені жирні кислоти окиснюються до альдегідів, що діють протимікозно. До складу лініментів і мазей включають саліцилову кислоту; вона розм'якшує епідерміс, що сприяє проникненню фунгіцидних препаратів у глибокі шари шкіри і пришвидшує регенерацію епітелію. Зручні в застосуванні аерозольні препарати. Менше ефективні присипки фунгіцидних препаратів.

\section{Таблиця 1}

Фунгіцидна ефективність протимікозних препаратів (Kaniuka, 2006)

\begin{tabular}{|c|c|c|c|c|c|c|c|c|c|c|}
\hline \multirow[b]{2}{*}{ Препарат } & \multicolumn{10}{|c|}{ Вид гриба } \\
\hline & $\begin{array}{c}\text { Трихофі- } \\
\text { тон } \\
\end{array}$ & $\begin{array}{c}\text { Мікроспо- } \\
\text { рон }\end{array}$ & $\begin{array}{c}\text { Епідермо- } \\
\text { фітон }\end{array}$ & $\begin{array}{l}\text { Аспер- } \\
\text { гілюс }\end{array}$ & $\begin{array}{c}\text { Кандидо- } \\
\text { мікоз } \\
\end{array}$ & $\begin{array}{c}\text { Крипто- } \\
\text { спорон }\end{array}$ & $\begin{array}{c}\text { Ботріомі- } \\
\text { цети }\end{array}$ & $\begin{array}{c}\text { Актино- } \\
\text { міцети }\end{array}$ & $\begin{array}{c}\text { Бластомі- } \\
\text { кози }\end{array}$ & $\begin{array}{c}\text { Гістоплаз- } \\
\text { ми } \\
\end{array}$ \\
\hline Ністатин & + & ++ & + & +++ & +++ & & & & & \\
\hline Леворин & & & & ++ & +++ & & & & & \\
\hline Гризеофульвін & +++ & +++ & ++ & - & & & & - & & \\
\hline Амфотерицин & - & - & ++ & ++ & +++ & & & - & ++ & ++ \\
\hline Амфоглюкамін & & & ++ & ++ & ++ & & & ++ & ++ & ++ \\
\hline Нітрофурилен & +++ & +++ & +++ & +++ & - & & & & & \\
\hline Нітрофунгін & +++ & +++ & +++ & & & & & & & \\
\hline Хлорімідазол & & & & ++ & ++ & & & & & \\
\hline Клотримазол & +++ & +++ & +++ & ++ & & & & & & \\
\hline Фунгідерм & ++ & ++ & ++ & ++ & & & & & & \\
\hline Міковет & +++ & +++ & +++ & ++ & ++ & & & & & \\
\hline Мікогептин & & & & ++ & ++ & ++ & ++ & & + & ++ \\
\hline Польфунгівет & ++ & ++ & ++ & +++ & & & & & & \\
\hline Фунгідермін & ++ & ++ & ++ & + & & & & & & \\
\hline
\end{tabular}

Примітка: + - проявляє дію, ++ - помірна дія, +++ - сильна дія, -- відсутність дії

Після розчищення копитець підошву обробляють $1 \%$ спиртовим розчином йоду 3 диметилсульфоксидом (10-15 мл 40\% ДМСО на 50 мл розчину йоду), 510 \% сульфату міді, 5 \% формальдегіду (Borysevych, 1993; Panko, 2003), а також 5-10 \% сульфату цинку (Kozii et al., 2018).

При дефектах рогу перед накладанням пов'язки окремі автори (Veremej et al., 1989) рекомендують застосування присипки: Acidi borici - 87,0; Acidi salicylici - 3,0; Jodoformii 10,0 або ж (для обробки рани) Acidi borici - 87,0; Acidi salicylici - 8,0; Xeroformii 5,0. Пов'язку необхідно змінювати через 2-3 дні, щоб забезпечити на рані сприятливе для лікування середовище. Зміну пов'язки виконують до того часу, доки рана не стане сухою й не почнеться іiї загоювання. 
Для лікування корів, хворих на гнійний пододерматит, спричинений дією кератолітичних грибів, рекомендують (Kulynych, 2012) проводити хірургічну обробку патологічного вогнища, після чого з інтервалом у 3-5 діб на ранову поверхню використовувати речовини, що проявляють виражену місцеву фунгіцидну дію (препарати 2-меркаптобензотіазолу, суміш нанокластерів аквахелатів $\mathrm{Ag}, \mathrm{Cu}, \mathrm{Zn}, \mathrm{Mg}$ ) шляхом триразового застосування просочених препаратами пов'язок із подальшою їх фіксацією на ратицях ортопедичним черевиком.

Схема лікування за гнійного пододерматиту, ускладненого кератоміцетами, така (Khomyn et al., 2020):

1) після знеболювання знімається весь зруйнований ріг;

2) поверхню дефекту зрошують $10 \%$ розчином натрію хлориду;

$3,4)$ на ділянку ураження впродовж 7 діб наносять розчин наноаквахелатів $\mathrm{Ag}, \mathrm{Cu}, \mathrm{Zn}$, просочують ним ватно-бинтовий тампон та до одужання - пантевенол (гель);

5) на уражені копитця накладають бинтову пов'язку та захисний чохол; таку пов'язку знімають через добу. Третю і наступні обробки проводять 3 інтервалом 5 діб. Розчин наноаквахелатів $\mathrm{Ag}, \mathrm{Cu}, \mathrm{Zn}$ володіє вираженою протизапальною, протинабряковою, бактерицидною, протигрибковою активністю, вираженим кератопластичним ефектом поряд 3 пенетруючими властивостями, що зумовлює його ефективність при багатьох захворюваннях зовнішніх покривів. Пантевенол чинить венотонічний, капіляротонічний, антиоксидантний, антиексудативний, гемостатичний ефекти. Препарат ефективно стимулює процеси регенерації тканин. Тривалість лікування складає 28 діб, що на 6 діб менше від традиційного способу. Ефективність лікування оцінюють за виповненням дефекту молодим трубчастим рогом.

За різних захворювань копитець показане використання лікувальних ванн. Купоросні (10 \% розчин мідного купоросу) або змішані (5\% розчин формаліну та $10 \%$ розчин мідного купоросу) ванни застосовують при лікуванні некробактеріозу, гнитті рогу м'якуша, верукозному пододерматиті тощо. Таке лікування доцільне при масовому ураженні копитець без накладання пов'язок (відкритий метод лікування). Поряд з обробкою копитець очищають і дезінфікують підлогу. Ванни сприяють швидшій демаркації, утворенню грануляційної тканини і епітелізації (Borisevich, 1996; Bergsten \& Herlin,1996).

Для лікування гнійно-некротичних процесів у ділянці пальця у великої рогатої худоби автори (Izdepskyi \& Kyrychko, 2009) рекомендують застосовувати пов'язки із санобітом. До складу згаданого препарату входять бішофіт полтавський, сорбенти кремнійорганічної породи і анестетик. Місцево застосований бішофіт виявляє протинабрякову, протизапальну, аналгетичну, імуностимулювальну та регенеративну властивості внаслідок активації клітинного імунітету і дії протеолітичних ферментів. Окрім того, бішофіт пригнічує ріст багатьох мікроорганізмів у вогнищі ушкодження.

Також отримані дані про позитивний терапевтичний ефект від застосування комплексної терапії лікування гнійних пододерматитів залежно від фази запального процесу: стадія гідратації - порошок “Діфазин” (діатоміт, сульфат цинку, стрептоцид, борна кислота) або порошок “Димефулін” (діатоміт, сульфат міді, перманганат калію, фурацилін) та на стадії дегідратації - антисептичну гідрофільну мазь “Левоміколь” (Ermolaev et al., 2016).

За даними авторів (Kovalchuk \& Kuzheliuk, 2015), лікування корів з ураженнями ратиць шляхом місцевого застосування $5 \%$ розчину йод-димексиду та внутрішньоаортального введення $0,5 \%$ розчину новокаїну з антибіотиками прискорює регенеративні процеси, що дозволяє скоротити термін лікування за пододерматитів та інших гнійно-некротичних захворювань пальця.

Багаторічні дослідження авторів (Makaev et al., 2012) вказують на високу ефективність для лікування захворювань дистального відділу кінцівок у великої рогатої худоби препаратів місцевої терапевтичної дії - “Фузосан-1” і “Фузобоксан-2”, а також “Хуф-фіт гель”. “Хуф-фіт гель” і “Фузосан-1” володіють припікаючою, протинабряковою та антисептичною дією. Їх накладають на пошкоджену ділянку після старанної хірургічної обробки. Для накладання пов'язки з цими препаратами використовують еластичні бинти, просякнуті спеціальним розчином "Хуф-фіт розчин”. "Хуффіт розчин” також можна використовувати для групової обробки кінцівок тварин. “Фузобоксан-2” - комплексний ін'єкційний препарат, який у своєму складі містить антимікробні, імуностимулюючі та регенеративностимулюючі компоненти.

За даними И. Г. Галимзянова та ін. (Galimzjanov et al., 2010), при лікуванні гнійно-некротичних захворювань пальців ВРХ вираженим терапевтичним ефектом володіє комплексне застосування іонообмінної тканини “Адсорбент" у поєднанні з трициліном або складним порошком на основі перманганату калію та борної кислоти 1:3 3 подальшим накладанням гіпсової пов'язки.

У схему лікування тварин доцільним є включення патогенетичної терапії, зокрема новокаїнових блокад, що сприяє швидкому видужанню тварин.

Циркулярна новокаїнова блокада: $0,25-0,5$ \% розчин новокаїну ін'єктують у верхній третині п'ясті (плесна) поблизу заднього краю відповідної кістки 3 латерального і медіального боків; після введення певної кількості розчину новокаїну голку під шкірою просувають наперед (дорсально), весь час натискаючи на поршень шприца, після чого повертають у попереднє положення і просувають назад (волярно), вводячи розчин. Вводять достатньо розчину, щоб інфільтраційні валики на дорсальній і волярній поверхнях з'єдналися між собою. При ураженні одного з копитець циркулярну новокаїнову блокаду виконують в ділянці першої фаланги відповідного пальця, застосовуючи $0,5 \%$ розчин новокаїну разом з антибіотиками. Ефективна також коротка новокаїнова блокада $з$ вве- 
денням новокаїн-антибіотикового розчину в міжпальцеву клітковину на рівні середини перших фаланг 3 дорсального чи волярного боку (Borisevich, 1996; Kirillov, 2007).

При більшості захворювань копитець досить ефективними є внутрішньосудинні ін'єкції: внутрішньовенні, аортальні, артеріальні. В яремну вену вводять 0,25-0,5 \% розчини новокаїну (1 мл/кг). Оскільки захворювання копитець проявляються в основному на тазових кінцівках, частіше використовують ін'єкції в аорту (150-300 мл); на грудних кінцівках новокаїнантибіотикові розчини вводять в серединну артерію.

Із загальних методів для підвищення резистентності організму, особливо при глибоких пододерматитах, зокрема спричинених чи ускладнених унгуломікозом, рекомендовано використовувати імуностимулювальні препарати, тканинні препарати, аутогемотерапію, опромінену ультрафіолетовими чи лазерними променями кров тощо. Але успіх лікування залежить не стільки від лікарських засобів, скільки від ретельної хірургічної обробки та післяопераційного захисту рани (Panko, 2003).

Профілактичні заходи зводяться до формування у тварин міцного копитцевого рогу, запобігання його руйнування та усунення сприятливих умов для розмноження кератоміцетів. Сюди належить повноцінна годівля, відповідні умови утримання та догляд за тваринами.

При порушенні процесів ороговіння (пододерматит, ламініт, нестача в раціоні сірки і сірковмісних амінокислот, порушенні метаболізму гістидину, лізину, аргініну, метіоніну, вітамінів, мікроелементів, зокрема міді, цинку, кобальту) в рогових клітинах різко знижується вміст дисульфідних груп, що свідчить про зміни молекулярної структури кератину і продукуванні менш стійкого рогу (Borisevich, 1996).

Саме тому у схемі профілактичних заходів численних захворювань копитець, зокрема унгуломікозу, вагоме місце відводиться профілактиці остеодистрофiï (Borisevich, 1996; Krupnyk et al., 2013), а також недопущення травматизму. Адже при виникненні запальних і деструктивних процесів в основі шкіри копитець настає порушення тканинної (трубчастої) i клітинної структури. Рогові трубочки мають різний діаметр, в них накопичується ексудат (за гнійного пододерматиту) або кров. В міжклітинний простір епідермісу проникають аномальні білковополісахаридні комплекси, які утворюються в основі шкіри при деградації колагену та із плазми крові, й відкладаються у вигляді цементуючих субстанцій. Ріг таких копитець зазнає змін у вигляді паракератозу і має вигляд аморфної рихлої войлокоподібної маси, яка просочена глікопротеїнами плазми крові і білками сполучнотканинного походження (Borisevich, 1996). Зрозуміло, що такий ріг стає сприятливим середовищем для розвитку мікроскопічних грибів.

Структурно-функціональні й метаболічні порушення в копитцевому розі, глибина і їх вираженість перебувають в тісному корелятивному зв'язку як зі ступенем, так і з формою деформації копитець. Виділяють “просту” деформацію та ускладнену запальни- ми й деструктивними процесами в основі шкіри (Borisevich, 1996). Оскільки деформовані копитця призводять до неправильної постави кінцівок, що своєю чергою ускладнює патологічний процес, то регулярна розчистка копитець займає чільне місце не тільки як лікувальний, а і як профілактичний захід (Kozii et al., 2018; Mar'in, 2019).

Такі порушення біофізичних властивостей копитцевого рогу, як сухість і м'ягкість, знижують його якість та експлуатаційні властивості. Тріщини зазвичай виникають при сухості, а м'якість призводить до деформації.

При сухості копитцевого рогу для ножних ван застосовують Sapo Viridis у воді (1 : 6); для просочування ватно-марлевої пов'язки Picis liquide + Ol.Ricini (1:4), Picis liquide + Ol.Vaselini (1:2), а також Natrii hidrokarbonatis 5 \%. Пов'язку накладають на копитця 3 сухим рогом на 24-48 годин, періодично зволожуючи iii. Зверху пов'язку захищають водонепроникним матеріалом. При м'якості копитцевого рогу для ножних ван застосовують Formaldehydi $5 \%$, Cupri sulfatis $10 \%$ (Veremej et al., 1989).

Копитцеві ванни підвищують механічну стійкість рогу, дезінфікують копитця. Зазвичай їх застосовують впродовж 2-3 днів 3 двотижневим інтервалом. Найпростіша ванна таких розмірів: довжина - 3-5 м; ширина - 1-2 м; глибина - 15-20 см; вхід і вихід із ванни має бути похилим. Одноразове заповнення ванни достатне для обробки 350-400 голів худоби, а при значному забрудненні копитець після прогону 150200 голів тварин ванну слід очистити й заповнити свіжим розчином. Треба брати до уваги те, що 5 \% розчин формаліну може викликати подразнення шкіри міжпальцевого склепіння, а при використанні міднокупоросних ванн необхідно не допускати заковтування розчину тваринами.

Рекомендується (Hulek, 2015) використовувати дві ванни глибиною 10-15 см і довжиною щонайменше 2,5 м; між ваннами має бути кілька метрів відстані, а за ними - місце для висихання копитець. Перша ванна заповнюється водою й призначена для очищення й відмивання від бруду; в другу ванну додають розчин 3 діючою речовиною. Беручи до уваги власний досвід, автор віддає перевагу регулярному прогону тварин у літній період по довгій ванні зі звичайною водою; коли ж виникає різке збільшення кількості випадків кульгання, зумовленого пальцевим дерматитом і міжкопитцевими інфекціями, використовується сульфат міді (зимою) чи формалін (влітку) двічі на тиждень, впродовж 2-3 тижнів.

Важливою ланкою в ліквідації і профілактиці мікозів є дезінфекція приміщень, в яких перебували хворі тварини. Більшість патогенних грибів, які викликають захворювання тварин, існують у зовнішньому середовищі у споровій формі, яка значно підвищує стійкість збудників мікозів. Вибір дезінфектантів та їх концентрацію визначають 3 урахуванням епізоотичної ситуації і результатів мікологічних досліджень. Для дезінфекції зазвичай застосовують лужні розчини 5 \% формальдегіду, мідного купоросу, креоліну, 5-10 \% гарячі розчини їдкого натрію, освітлені 
розчини хлорного вапна із вмістом 3-5 \% активного хлору та ін. Для побілки використовують 10-20\% свіжогашене вапно. Також дезінфікують і предмети догляду за тваринами парами формальдегіду в параформалінових камерах. В неблагополучних щодо дерматомікозів господарствах шкіру тварин обробляють фунгіцидними препаратами (Harchenko et al., 1982).

Важливе значення для профілактики мікозів має повноцінна годівля і добрі умови утримання тварин, які підвищують резистентність організму (Borisevich, 1996; Kirillov, 2007; Rukol', 2013; Solano et al., 2015; Moreira et al., 2019; Langova et al., 2020; Mylostyvyi et al., 2021).

\section{Висновки}

1. Мікроскопічні гриби-кератоміцети є етіологічним чинником зниження механічної стійкості та руйнування копитцевого рогу, що спричиняє виникнення деформацій копитець, розвиток пододерматиту та ураження копитцевої кістки.

2. Грибкова флора є одним із факторів ускладнення перебігу асептичного чи гнійного пододерматиту.

3. Лікування поверхневого унгуломікозу включає розчистку копитець та їх антисептичну обробку у вигляді фунгіцидних присипок, спреїв, копитцевих ванн.

4. За глибокого унгуломікозу, особливо у поєднанні з гнійним пододерматитом, лікування включає місцеве знеболювання, ортопедичну розчистку, антисептичну обробку з накладанням захисної пов'язки, патогенетичну терапію.

5. Профілактичні заходи грунтуються на формуванні у тварин міцного копитцевого рогу, запобіганні його руйнування та усунення сприятливих умов для розмноження мікроскопічних грибів-кератоміцетів.

\section{Відомості про конфлікт інтересів}

Автори стверджують про відсутність конфлікту інтересів.

\section{References}

Bergsten, C., \& Herlin, A. H. (1996). Sole Haemorrhages and Heel Erosion in Dairy Cows: The Influence of Housing Sustem on their Prevalence and Severity. Acta Vet Scand, 37(4), 395-408. doi: 10.1186/BF03548079.

Borisevich, V. B. (1996). Bolezni kopytec i kopyt. Kyiv (in Russian).

Borysevych, V. B. (1993). Unhulomikoz. Spetsialna veterynarna khirurhiia. K.: Vyd-vo USHA, 433-434 (in Ukrainian).

Chehodaridi, F. N., \& Guchkaeva, M. S. (2019). Klinikoortopedicheskaja dispanserizacija dojnogo stada. Perspektivy razvitija APK v sovremennyh uslovijah. Mater. 8-j Mezhd. nauch.-prakt. konf. Gorskij GAU (Vladikavkaz), 97-98 (in Russian).

Ermolaev, V. A., Mar'in, E. M., Ljashenko, P. M., \& Sapozhnikov, A. V. (2016). Regeneracionnye i disre- genera-cionnye processy pri lechenii podo-dermatitov u korov. Vestnik Altajskogo gosudarstvennogo agrarnogo universiteta, 12(146), 120-130. URL: https://cyberleninka.ru/article/n/regeneratsionnye-idisregeneratsionnye-protsessy-pri-lecheniipododermatitov-u-korov/viewer (in Russian).

Galimzjanov, I. G., Kutlukaev, I. I., \& Shakurov, M. Sh. (2010). Tkan' "Adsorbent" pri lechenii gnojnonekroticheskih porazhenij pal'cev krupnogo rogatogo skota. Uchenye zapiski Kazanskoj gosudarstvennoj aka-demii veterinarnoj mediciny im. N.Je. Baumana, 203, 73-78 (in Russian).

Harchenko, S. N., Litvin, V. P., \& Tarabara, I. M. (1982). Spravochnik po mikozam i mikotoksikozam sel'skoho-zjajstvennyh zhivotnyh. K.: Urozhaj (in Russian).

Hulek, M. (2015). Zdorov'e kopyt i uhod za nimi. K.: OOO “Agrar Medien Ukraina” (in Russian).

Izdepskyi, V. I., \& Kyrychko, B. P. (2009). Deiaki pytannia patohenezu hniino-nekrotychnykh protsesiv dilianky pal-tsia u vysokoproduktyvnykh tvaryn. Problemy zooinzhenerii ta veterynarnoi medytsyny, 9(33), 62 (in Ukrainian).

Izdepskyi, V. I., Kulynych, S. M., \& Kabluchko, A. P. (2012). Deiaki biokhimichni pokaznyky vplyvu mikroskopichnykh hrybiv na tkanyny kopytnoho rohu u tvaryn. Nauk. visnyk vet. medytsyny: Zb. nauk. prats. Bila Tserkva, 9(92), 66-70 (in Ukrainian).

Kaniuka, O. I. (2006). Klinichna veterynarna farmakolohiia. Odesa: Astroprynt (in Ukrainian).

Kantemyr, O. V., Anichyn, A. M., \& Movnar, V. V. (2016). Rezultaty ortopedychnoi dyspanseryzatsii poholivia koriv NPTs tvarynnytstva i roslynnytstva Khar-kivskoi derzhavnoi zooveterynarnoi akademii. Problemy zooinzhenerii ta veterynarnoi medytsyny, 32(2), 36-38 (in Ukrainian).

Khomyn, N., Mysak, A., Tsisinska, S., \& Pritsak, V. (2017). The quality of the hoof horns of cattle and the influence of certain etiological factors. Scientific Messenger of LNU of Veterinary Medicine and Biotechnologies. Series: Veterinary Sciences, 19(82), 175-179. URL: https://nvlvet.com.ua/index.php/journal/article/view/1360 (in Ukrainian).

Khomyn, N., Mysak, A., Tsisinska, S., Pritsak, V., Nazaruk, N., \& Lenjo, Y. (2020). Features of cows treatment with purulent pododermatitis complicated by keratomycetes. Scientific Messenger of LNU of Veterinary Medicine and Biotechnologies. Series: Veterinary Sciences, 22(99), 94-100. doi: 10.32718/nvlvet9915.

Kirillov, A. A. (2007). Kompleksnyj metod lechenija korov, bol'nyh gnojnym pododermatitom : avtoref. dis. kandid. vet. nauk: 16.00.05 - veterinarnaja hirurgija. Cankt-Peterburgskaja gosudarstvennaja akademija veterinarnoj mediciny. Sankt-Peterburg (in Russian).

Kovalchuk, Yu. V., \& Kuzheliuk, R. L. (2015). Deformatsiia ratyts $\mathrm{u}$ koriv: korektsiia ta profilaktyka, likuvannia uskladnen. Ahrarna nauka, osvita, vyrobnytstvo: yevropeiskyi dosvid dlia Ukrainy: materialy naukovo-praktychnoi konferentsii. Zhytomyr, 306309 (in Ukrainian). 
Kozii, V. I., Vlasenko, V. M., Rublenko, M. V., Bohachyk, O. H., Petryk, M. V., Lypko, Ya., \& Andriiets, V. H. (2018). Profilaktyka khvorob kintsivok u koriv (dobrobut tvaryn, rozchystka ratyts, antyseptychni zasoby): navch. Posibnyk. Ukladachi: Bila Tserkva (in Ukrainian).

Krasnoperov, A. S., Belousov, A. I., Halturina, L. V., Malkov, S. V., \& Mil'shtejn, I. M. (2020). Klinikoortopedicheskaja dispanserizcija korov pri besprivjaznom soderzhanii. Veterinarija Kubani, 5. doi: 10.33861/2071-8020-2020-5-14-17 (in Russian).

Krupnyk, Y., Tsisinska, S., \& Lenjo, Y. (2021). Ungulomycosis of cattle: etiological factors and pathogenetic mechanisms. Scientific Messenger of LNU of Veterinary Medicine and Biotechnologies. Series: Veterinary Sciences, 23(101), 100-106. doi: 10.32718/nvlvet10117

Krupnyk, Ya. H., Mysak, A. R., Tsisinska, S. V., \& Demydiuk, S. K. (2013). Osteodystrofiia velykoi rohatoi khudoby: os-novni faktory, patohenetychni mekhanizmy, profilaktychni zakhody. Veterynarna medytsyna Ukrainy, 7(209), 15-21 (in Ukrainian).

Kulynych, S. M. (2012). Urazhennia kopytets u koriv, sprychyneni keratomitsetamy: avtoref. dys. d-ra vet. nauk; 16.00.05 - veterynarna khirurhiia. Nats. un-t bioresursiv i pryrodokorystuvannia Ukrainy. Kyiv (in Ukrainian).

Langova, L., Novotna, I., Nemcova, P. et al. (2020). Impact of Nutrients on the Hoof Health in Cattle. Animals, 10(10), 1824. doi: 10.3390\%2Fani10101824.

Luk'janovskij, V. A. (2005). Biotehnologicheskie zakonomernosti vozniknovenija ortopedicheskih boleznej u korov. Veterinarija, 9, 52-57 (in Russian).

Mahda, I. I., Vlasenko, V. M., \& Voronin, I. I. (1995). Operatyvna khirurhiia tvaryn z osnovamy topohrafichnoi anatomii i anesteziolohii. Kyiv: Vyshcha shkola (in Ukrainian).

Makaev, H. N., Huzin, D. A., Potehina, R. M., \& Muhammetshin, H. A. (2012). Profilakticheskaja jeffektivnost' razlichnyh sredstv i metodov lechenija nekroticheskih porazhenij kopytec krupnogo rogatogo skota. Uchenye zapiski Kazanskoj gosudarstvennoj akademii vet. mediciny im. N.Je. Baumana, 209, 202-206. URL: https://cyberleninka.ru/article/n/profilakticheskay a-effektivnost-razlichnyh-sredstv-i-metodov-lecheniyanekroticheskih-porazheniy-kopytets-krupnogorogatogo-skota/viewer (in Russian).

Malishevs'kij, E. A., Zavirjuha, V. I., Gamota, A. A., Misak, A. R., \& Samsonjuk, V. G. (1991). Ungulomikoz u krupnogo rogatogo skota. Problemy hirurgicheskoj patologii sel'skohozjajstvennyh zhivotnyh. Tez. dokl. Vsesojuzn. Nauch. konf. Belaja Cerkov', 88-89 (in Russian).

Mar'in, E. M. (2019). Hirurgicheskie bolezni v oblasti pal'cev u korov i ih kompleksnoe lechenie sorbcionno-antisepticheskimi preparatami avtoref. dis. d-ra vet. nauk: 06.02.04 - veterinarnaja hirurgija. San-ktPeterburgskaja gosudarstvennaja akademija veterinarnoj mediciny. Sankt-Peterburg (in Russian).

Mar'in, E. M., Ermolaev, V. A., \& Kireev, A. V. (2017). Rasprostranjonnost' ortopedicheskih patologij u korov i lechenie gnijnyh pododermatitov. Vestnik
Ul'janovskoj gosudarstvennoj sel's'kohozjajstvennoj akademii, 2(1), 135-142 (in Russian).

Mar'in, E. M., Ermolaev, V. A., Mar'ina, O. N., \& Raksina, I. S. (2012). Harakteristika ortopedicheskih patologij u krupnogo rogatogo skota. Vestnik Ul'janovskoj gosudarstvennoj sel'skohozjajstvennoj akademii, 4, 66-69. URL: https://cyberleninka.ru/article/n/harakteristikaortopedicheskih-patologii-u-krupnogo-rogatogo-skota (in Russian).

Moreira, T. F., Nicolino, R. R., Meneses, R. M., Fonseca, G. V., Rodrigues, L. M., Filho, E. J. F., \& Carvalho, A. U. (2019). Risk factors associated with lameness and hoof lesions in pasture-based dairy cattle systems in southeast Brazil. J. Dairy Sci., 102, 10369-10378. doi: $10.3168 /$ jds.2018-16215.

Mylostyvyi, R., Sejian, V., Izhboldina, O., Kalinichenko, O., Karlova, L., Lesnovskay, O., Begma, N., Marenkov, O., Lykhach, V., Midyk, S., Cherniy, N., Gutyj, B., \& Hoffmann, G. (2021). Changes in the Spectrum of Free Fatty Acids in Blood Serum of Dairy Cows during a Prolonged Summer Heat Wave. Animals, 11(12), 3391. doi:.org/10.3390/ani11123391.

Nenashev, I. V., Mar'in, E. M., \& Mar'ina, O. N. (2018). Ortopedicheskaja zabolevaemost' golshtinizirovannyh korov v uslovijah besprivjaznogo soderzhanija. Vestnik gosudarstvennoj sel'skohozjajstvennoj akademii, 190-194. doi: 10.18286/1816-4501-2018-4-190194 (in Russian).

Panko, I. S. (2003). Unhulomikoz. Spetsialna veterynarna khirurhiia. Bila Tserkva: BDAU (in Ukrainian).

Povazhenko, I. E., \& Borisevich, V. B. (1987). Bolezni konechnostej zhivotnyh. K.: Urozhaj (in Russian).

Rudyk, S., Yaroshenko, V., \& Rybalko, V. (2021). Zakhody $\mathrm{z}$ profilaktyky zakhvoriuvan kintsivok VRKh. Ahrarnyi sektor Ukrainy (in Ukrainian).

Rukol', V. M. (2013). Tehnologicheskie osnovy veterinarnogo obsluzhivanija molochnogo krupnogo rogatogo skota s hirurgicheskimi boleznjami v Respublike Belarus' : avtoref. dis. d-ra vet. nauk: 06.02.04 veterinar-naja hirurgija. Sankt-Peterburgskaja gosudarstvennaja akademija veterinarnoj mediciny. SanktPeterburg (in Russian).

Solano, L., Barkema, H. W., Pajor, E. A., Mason, S., LeBlanc, S. J., Zaffino Heyerhoff, J. C., Nash, C. G. R., Haley, D. B., Vasseur, E., Pellerin, D. et al. (2015). Prevalence of lameness and associated risk factors in Canadian Holstein-Friesian cows housed in freestall barns. J. Dairy Sci., 98, 6978-6991. doi: $10.3168 /$ jds.2015-9652.

Spitsyna, T. L., Koreiba, L. V., \& Tkachuk, I. H. (2016). Rozpovsiudzhennia khvorob dystalnoho viddilu kintsivok u koriv i netelei v umovakh Pr-AT "AhroSoiuz" Dnipropetrovskoi oblasti. konf. Dnipropetrovskyi DAEU (in Ukrainian).

Stekol'nikov, A. A., Semjonov, B. S., Molokanov, V. A., \& Veremej, Je. V. (2016). Veterinarnaja ortopedija: uchebnik dlja vuzov. Izdatel'stvo Jurajt (in Russian).

Veremej, Je. I., \& Zhurba, V. A. (2003). Rasprostranenie i profilaktika zabolevanij pal'cev i kopytec u kru-pnogo rogatogo skota. Veterinarnaja medicina Belarusi, 2, 32-35 (in Russian). 
Veremej, Je. I., Eliseev, A. N., \& Luk'janovskij, V. A. (1989). Spravochnik po primeneniju lekarstvennyh sredstv v veterinarnoj hirurgii. Mn.: Uradzhaj (in Russian).

Vlasenko, V. M., \& Tykhoniuk, L. A. (2000). Veterynarna anesteziolohiia: Navchalnyi posibnyk. Bila Tserkva (in Ukrainian).
Vlasenko, V. M., Tykhoniuk, L. A., \& Rublenko, M. V. (2006). Operatyvna khirurhiia, anesteziolohiia i topohrafichna anatomiia. Bila Tserkva (in Ukrainian). 